\title{
EXPOSURE TO URBAN AIR POLLUTION AND BONE HEALTH IN CLINICALLY HEALTHY SIX-YEAR-OLD-CHILDREN
}

\author{
Lilian CALDERÓN-GARCIDUEÑAS ${ }^{1}$, Antonieta MORA-TISCAREÑO ${ }^{2}$, Maricela FRANCO- \\ LIRA $^{3}$, Ricardo TORRES-JARDÓN ${ }^{4}$, Bernardo PEÑA-CRUZ², Carolina PALACIOS-LÓPEZ ${ }^{2}$, \\ Hongtu $\mathrm{ZHU}^{5}$, Linglong $\mathrm{KONG}^{5}$, Nicolás MENDOZA-MENDOZA ${ }^{2}$, Hortencia MONTESINOS- \\ CORREA $^{2}$, Lina ROMERO ${ }^{2}$, Gildardo VALENCIA- SALAZAR ${ }^{2}$, Michael KAVANAUGH $^{1}$, \\ Silvestre FRENK ${ }^{2}$
}

The Center for Structural and Functional Neurosciences, The University of Montana, Missoula, MT, USA ${ }^{1}$, Instituto Nacional de Pediatría ${ }^{2}$, Hospital Central Militar ${ }^{3}$, Centro de Ciencias de la Atmósfera ${ }^{4}$, Universidad Nacional Autónoma de México, Mexico City, Mexico, Biostatistics, University of North Carolina Gillings School of Global Public Health, Chapel Hill ${ }^{5}$, NC, USA

Received in February 2012

CrossChecked in December 2012

Accepted in July 2012

\begin{abstract}
Air pollution induces systemic inflammation, as well as respiratory, myocardial and brain inflammation in children. Peak bone mass is influenced by environmental factors. We tested the hypothesis that six-yearolds with lifetime exposures to urban air pollution will have alterations in inflammatory markers and bone mineral density (BMD) as opposed to low-polluted city residents when matched for BMI, breast feeding history, skin phototype, age, sex and socioeconomic status. This pilot study included 20 children from Mexico City (MC) (6.17 years \pm 0.63 years) and 15 controls (6.27 years \pm 0.76 years). We performed full paediatric examinations, a history of outdoor exposures, seven-day dietary recalls, serum inflammatory markers and dual-energy X-ray absorptiometry (DXA). Children in MC had significantly higher concentrations of IL-6 $(p=0.001)$, marked reductions in total blood neutrophils $(p=0.0002)$ and an increase in monocytes $(p=0.005)$. MC children also had an insufficient Vitamin D intake and spent less time outdoors than controls $(p<0.001)$ in an environment characterized by decreased UV light, with ozone and fine particulates concentrations above standard values. There were no significant differences between the cohorts in DXA Z scores. The impact of systemic inflammation, vitamin D insufficiency, air pollution, urban violence and poverty may have long-term bone detrimental outcomes in exposed paediatric populations as they grow older, increasing the risk of low bone mass and osteoporosis. The selection of reference populations for DXA must take into account air pollution exposures.
\end{abstract}

KEY WORDS: DXA, particulate matter, systemic inflammation, UV light, vitamin D insufficiency

Environmental pollutants, chemicals and metals have a negative health impact on children $(1,2)$. There is evidence that exposure to air pollution can result in long-lasting health problems (3-10). Vitamin D deficiency and rickets are associated with air pollution, indoor confinement during the day, residency at higher altitudes and darker skin pigmentation $(11,12)$. Systemic inflammation likely plays a critical role in bone metabolism through interleukin 6 (IL-6), a multifunctional cytokine that participates in 
inflammation, regulates immune responses and has osteoclastic effects with its increased bone-resorption (13). Several studies involving elderly populations have shown that cumulative air pollution concentrations are inversely associated with total body bone mineral density (BMD) (14).

Since childhood and adolescence are crucial periods for skeletal and biochemical bone change, children are a population at risk. Given that nutritional vulnerability is a key aspect in children's growth, our pilot study focused on the evaluation of the impact of air pollutant exposures in two cohorts of six-year-old children residents of two environments with distinctly different levels of pollution.

The primary purpose of this work was to evaluate the bone mineral density as measured by the dualenergy X-ray absorptiometry (DXA) in six-year-olds with a lifetime residency in a highly polluted city (Mexico City) versus a control group from a city with levels well below the current USA National Ambient Air Quality Standards (NAAQS) (Polotitlán, Mexico State). We aimed to identify possible associations between blood inflammatory markers, bone mineral density and nutritional intake in the selected cohorts. Due to the fact that Mexico City children spend less time outdoors and live in a UV blocking environment caused by smog, we expected to find alterations in DXA measurements and inflammatory markers.

\section{Air pollution}

The Mexico City metropolitan area is the largest urban centre of North America and an example of extreme urban growth as well as of the accompanying environmental pollution (15). This metropolitan area of over 2000 square kilometres lies in an elevated basin $2240 \mathrm{~m}$ above mean sea level, while its urbanized area is surrounded on three sides by mountain ridges with a broad opening to the north and a narrow gap to the south-southwest. In this geographical setting, 20 million inhabitants (including 9 million children), over 40,000 industries and 4 million vehicles consume more than 40 million litres of petroleum fuels per day, producing an estimated annual emission of 2.6 tons of pollutants including coarse and fine particulate matter, gaseous pollutants, polycyclic aromatic hydrocarbons, and lipopolysaccharides (15). As a result of high emissions of secondary precursors (nitrogen oxides and volatile organic compounds), ozone concentrations peak in the downwind southwest area in the afternoon, in accordance with the typical diurnal wind transport of air polluted masses. The higher short-term (i.e., hourly averages) fine particulate matter (particles with a diameter less than $2.5 \mu \mathrm{m}$, $\mathrm{PM}_{2.5}$ ) concentrations coincide with periods when children are outdoors during school recess and physical education, whereas maximal $\mathrm{O}_{3}$ levels coincide with when they play outdoors at home (16).

Due to high traffic density and increased energy usage, MC suffers from high levels of particulate black carbon (BC) pollution (15). The dominant lightabsorbing aerosol species in the region is likely to be $\mathrm{BC}$, commonly known as carbon soot, as well as the associated organic carbon, both of which are produced by diesel engines within the urban area and by the incomplete combustion of fossil fuel biomass burning in the surrounding rural areas. The absorption of solar light by freshly emitted BC aerosols is broadband, although they are more efficient in the UVB range $(280 \mathrm{~nm}$ to $315 \mathrm{~nm})$. The presence of highly absorbing fine mode aerosols in MC is expected to reduce the UV flux at ground level and therefore lessen the photochemical production of oxidants such as ozone (17). However, under certain meteorological circumstances, the presence of fine mode scattering aerosols in the boundary layer of the Mexico City air basin that are similar in size as the wavelength of the incoming UV radiation may also increase in the UVB flux at ground level. This is due to their ability to strongly scatter light in the forward direction. In turn, this increase in UV-B flux leads to an increase in photochemical pollution (18). Nevertheless, the net reduction effect in UV-B radiation is predominant (18).

The selection of children from Southwest Mexico City (SW MC) was based on three factors: i. the SW location of the paediatric hospital, ii. children living and attending school close to the hospital, and iii. the location of the $\mathrm{MC}$ air pollution monitoring stations: Pedregal and Coyoacán. The control city Polotitlán is a small town $2300 \mathrm{~m}$ above mean sea level and 73 miles Northwest of Mexico City with an estimated population of 3000 residents. Its main activity is agriculture along with a few small dairy plants. In contrast to Mexico City, in Polotitlán all criteria pollutants $\left(\mathrm{O}_{3}, \mathrm{PM}_{10}, \mathrm{SO}_{2}, \mathrm{NO}_{2}, \mathrm{CO}\right.$ and $\left.\mathrm{Pb}\right)$ are below the current US standards due to the fortunate combination of a relatively small number of contributing industrial and traffic emission sources and good ventilation conditions due to regional winds. 


\section{PROCEDURES}

\section{Study areas and children's cohorts}

This prospective pilot protocol was approved by the review boards and ethics committee at the Hospital Central Militar, and performed according to the Declaration of Helsinki. Written consent was obtained from parents and verbal consent from the children. The geographic areas selected for this study were Southwest Mexico City and Polotitlán. The children belonged to the same socioeconomic status and attended public schools with identical academic and physical education curricula.

\section{Participants}

This study includes data from 20 children from Mexico City (Mean age $=6.17$ years, $S D=0.63$ years) and 15 control children (Mean age $=6.27$ years, $S D=$ 0.76 years). The criteria for clinical inclusion were: a negative smoking history and environmental tobacco exposure, lifelong residency in MC or in the control city, residency within 5 miles of the city monitoring stations, full term birth, breastfeeding period of $\geq 6$ to $\leq 12$ months, and unremarkable clinical histories. The exclusion criteria included: i. height or weight below the third percentile or above the 97 percentile ii. premature birth, iii. a history of any type of fracture, iv. any systemic disease, $v$. intake of any prescribed or other medications including vitamins and dietary supplements vi. a first degree relative with primary osteoporosis. Outdoor daily exposures in hours per day were recorded by the mother during seven days, including the transit time to and from school, the time spent on recess and physical education during school, and outdoor time while playing and engaging in other activities.

\section{Paediatric and dermatological examination}

Complete clinical histories were performed and the children underwent physical examinations. The dermatologist examined the children to establish the type of skin according to the Fitzpatrick Classification Scale (19). Fasting blood samples were collected between 7:00 and 9:00 am. Blood samples in the MC cohort were collected the same week as in the control cohort.

\section{Evaluation of nutritional intake}

A paediatric nutritionist interviewed the child and asked the mother to keep a detailed written seven-day food intake record, including the weekend.

\section{Peripheral blood analysis}

Blood samples were taken for a Comprehensive Metabolic Panel (CMP) and custom made human Multiplexing Laser Bead Technology (Eve Technologies Corporation, Calgary, Alberta, Canada) for the quantification of the following markers: epidermal growth factor EGF, Eotaxin, fibroblast growth factor-2 FGF-2, Fit-3L, Fractalkine, Granulocyte colony stimulating factor G-CSF, Granulocyte/ macrophage colony stimulating factor GM-CSF, Growth-related oncogene GRO, Interferon alpha 2 IFN $\alpha 2$, Interferon gamma IFN $\gamma$, Interleukin 1 alpha IL-1 $\alpha$, IL-1 $\beta$, IL-1ra, IL-2, IL-3, IL-4, IL-5, IL-6, IL-7, IL-8, IL-9, IL-10, IL-12 (p40), IL-12 (p70), IL-13, IL-15, IL-17, Inducible protein 10 IP-10, Monocyte chemotactic protein MCP-1, MCP-3, Macrophage inflammatory protein 1 alpha MIP- $1 \alpha$, MIP-1 $\beta$, Platelet-derived growth factor PDGF-AA, PDGF-AB/BB, Regulated upon Activation, Normal T-cell Expressed, and Secreted protein RANTES, Soluble CD40 ligand sCD40K, Membrane bound/ soluble IL-2 receptor alpha sIL-2R $\alpha$, Transforming growth factor alpha $\mathrm{TGF} \alpha$, Tumour necrosis factor alpha TNF $\alpha$, TNF $\beta$, and Vascular endothelial growth factor VEGF.

\section{TLR4 Genotyping}

DNA was isolated from peripheral blood and genotyped for the presence of the Asp299Gly Toll-like receptor-4 (TLR-4) polymorphism, using an allelic discrimination assay protocol according to Applied Biosystems (Life Technologies Corporation, Carlsbad, CA).

\section{Dual energy X-ray absorptiometry (DXA)}

The entire body, spine, bilateral forearm and femur scans were acquired by a Lunar Prodigy Advance Encore 2004, General Electric using the Lunar version 8.80 software. Given that our main focus was exposure to distinct polluted environments, and considering that the selected children were healthy, we used $\mathrm{Z}$ scores based on the low-pollution matched population and compared them to the exposed MC children.

\section{Measurement of bone age}

A single X-ray of the left wrist, hand and fingers was taken for measurement of bone age following the Greulich and Pyle methodology (20). 


\section{Data analysis}

The univariate descriptive measurements of the two groups' characteristic variables were calculated along with $95 \%$ confidence intervals and $p$ values of two sample t-tests for differences between two group means. The Gaussian distribution was assumed in the inference procedures, i.e. confidence intervals and two sample t-tests. The laboratory data and nutritional intake data were analysed using the same method as the characteristic variables assuming Gaussian distribution. A paired t-test was used to compare the mean difference between the chronological and bone age of Mexico City children and the controls assuming Gaussian distribution. The Z-score of the BMD DXA was calculated based on the control population with life exposures to air pollutants below the standards. For calculating $\mathrm{Z}$ scores, the BMD value was $\mathrm{X}$, while MU and SIGMA were the mean and standard deviation of that variable of the control population, respectively. The Z-score of X was defined as (X-MU)/SIGMA. The Z-scores were analysed using inference procedures such as laboratory data and nutritional intake data. Simple linear regression was conducted between total peripheral neutrophils and DXA variables. The $r$-squares of linear regression and $p$ values for testing linear relationship were calculated. Statistical analyses were performed using R version 2.13 (http://www.rproject.org/). Univariate descriptive measurements were summarized as mean values \pm standard deviations. Significance was assumed if either $95 \%$ confidence intervals did not cover zero or at $p<0.05$. The strength of the simple linear relationship was summarized as r-squares.

\section{RESULTS}

\section{Air pollution levels}

Mexico City children involved in this study had been exposed to significant concentrations of $\mathrm{O}_{3}$ and particulate matter (PM) for their entire life (15). The climatic conditions in $\mathrm{MC}$ are relatively stable and thus pollutant concentrations are consistent year after year. In the years from 2007 through 2009, which includes the study period, $\mathrm{PM}_{25}$ annual average concentrations in SW MC were (16.84 \pm 8.04$) \mu \mathrm{g} \mathrm{m}^{-3}$; $(17.96 \pm 8.34) \mu \mathrm{g} \mathrm{m}^{-3}$; and $(18.39 \pm 8.69) \mu_{\mathrm{g} \mathrm{m}^{-3}}$, respectively (the US EPA annual standard calls for an $\mathrm{PM}_{2.5}$ annual average limit of $15 \mu \mathrm{g} \mathrm{m}^{-3}$ ). In addition, the fourth highest daily maximum 8-hour average ozone concentrations for the same years in that same part of MC were $240 \mu^{-3 m^{-3}}(0.121 \mathrm{ppm}), 250 \mathrm{\mu g} \mathrm{m}^{-3}$ $(0.126 \mathrm{ppm})$ and $244 \mu \mathrm{g} \mathrm{m}^{-3}(0.123 \mathrm{ppm})$, respectively (the ozone US EPA air quality standard stands for an annual fourth-highest daily maximum 8-hour concentration of $149 \mu \mathrm{g} \mathrm{m}^{-3}(0.075 \mathrm{ppm})$. In the control location, pollutant concentrations had been below the current US EPA standards since 2003 (21). UV-B levels at ground level had been lower in MC than in the surrounding rural locations because of the attenuation effect of the polluted urban air in Mexico City (22). Typically, the UV-B reduction increases from Northeast towards Southwest over MC following the same spatial pattern of the oxidant levels. Acosta and Evans (22) reported that by 1996, the reduction in UV-B in the urban area was greater than $40 \%$ compared with surrounding rural areas in highly polluted days, while the yearly average reduction was around $20 \%$. Even though this effect has been diminished in the last decade due to the decrease in air pollution levels, the UV light reduction persists due to the presence of highly absorbing aerosols (17).

\section{Demographic data and physical exams}

Table 1 summarizes the characteristics of the matched samples. There were 15 children from Polotitlán ( 8 female, 7 male) and 20 children from Mexico City ( 8 female, 12 male). Controls spent more time outdoors than MC kids [CTL (4.3 \pm 0.5$) \mathrm{h}, \mathrm{MC}$ $(3.5 \pm 0.2) \mathrm{h}, p<0.001]$. The predominant skin type was type IV with $14 \%$ of children with type III skin.

\section{Laboratory findings}

Mexico City children exhibited significantly higher IL 6 concentrations $(p=0.001)$, while they had significant reductions in WBC $(p=0.0002)$ and total neutrophils $(p=0.0002)$, and increases in monocytes $(p=0.005)$ (Table 2). There were no significant differences in the concentrations of the custom made human Multiplexing Laser Bead Technology inflammatory panel, except IL-6 (Supplemental Table 1). Total serum alkaline phosphatase was within normal limits in both cohorts. GGT and $\mathrm{Ca}$ concentrations were significantly higher in Controls $(p<0.0001$ and $p<0.0002$, respectively) but remained within our normal concentration range for age and gender. 
Table 1 Characteristics of the groups of children studied: Mexico City versus controls

\begin{tabular}{|c|c|c|c|c|}
\hline & & & & \\
\hline & $\begin{array}{l}\text { Controls } \\
\qquad N=15\end{array}$ & $\begin{array}{c}\text { Mexico City } \\
\qquad=\mathbf{2 0}\end{array}$ & $\begin{array}{c}\text { Confidence } \\
\text { Intervals } \\
\text { Lower / upper limits }\end{array}$ & $p$ value \\
\hline Birth weight / g & $2952 \pm 655$ & $3144 \pm 411$ & $-206.8039 / 592.5039$ & 0.32 \\
\hline Weight / kg & $20.4 \pm 3.94$ & $21.2 \pm 3.5$ & $-1.9129 / 3.3795$ & 0.57 \\
\hline Height / m & $1.15 \pm 0.06$ & $1.14 \pm 0.04$ & $-0.0442 / 0.0375$ & 0.86 \\
\hline $\mathrm{BMI} / \mathrm{kg} \mathrm{m}^{-2}$ & $15.14 \pm 2.23$ & $15.99 \pm 1.84$ & $-0.6066 / 2.3009$ & 0.24 \\
\hline Outdoor / h & $4.3 \pm 0.5$ & $3.5 \pm 0.2$ & & $<0.001$ \\
\hline Gender & $8 \mathrm{~F} / 7 \mathrm{M}$ & $8 \mathrm{~F} / 12 \mathrm{M}$ & & \\
\hline Skin type * & IV13/III 2 & IV 17/III 3 & & \\
\hline
\end{tabular}

Note: The numerical values shown in the table represent means \pm 1 standard deviation as well as $95 \%$ confidence intervals and $p$ values of two sample t-test for difference between two group means. *The skin classification was based on the Fitzpatrick Classification Scale

Supplemental Table 1 Profile of inflammatory mediators and differences between controls and Mexico City children

\begin{tabular}{|c|c|c|c|}
\hline & LCI95* & UCI95** & $p$ values \\
\hline Eotaxin & -23.8085 & 22.0638 & 0.9350 \\
\hline FGF-2 & -9.4529 & 27.7549 & 0.3200 \\
\hline Flt3Ligand8 & -2.9167 & 11.8896 & 0.2215 \\
\hline Fractalkine & -81.9580 & 72.7337 & 0.9013 \\
\hline G-CSF & -5.8497 & 0.3504 & 0.0773 \\
\hline M-CSF & 122.3757 & 35.4183 & 0.2625 \\
\hline GRO & 102.0811 & 131.2136 & 0.7980 \\
\hline IFN alpha & -17.2324 & 16.1459 & 0.9457 \\
\hline IFN gamma & -64.6281 & 22.3666 & 0.3010 \\
\hline IL-1alpha & -2.9672 & 2.2823 & 0.7801 \\
\hline IL-1beta & -3.4480 & 11.8436 & 0.2688 \\
\hline IL-1ra & -4.7605 & 4.1485 & 0.8843 \\
\hline IL-2 & -3.0833 & 3.6024 & 0.8742 \\
\hline IL-4 & -4.0242 & 0.9682 & 0.2056 \\
\hline IL-8 & -1.9160 & 1.9586 & 0.9819 \\
\hline IL-9 & -0.3029 & 0.1940 & 0.6498 \\
\hline IL10 & -3.9318 & 1.3598 & 0.3017 \\
\hline IL-12 & -54.3925 & 26.4674 & 0.4658 \\
\hline IL-12 (p70) & -15.1739 & 5.2806 & 0.3061 \\
\hline IL13 & -8.4969 & 2.1742 & 0.2135 \\
\hline IL15 & -1.0563 & 1.6898 & 0.6392 \\
\hline IL-17 & -1.5796 & 0.7987 & 0.4978 \\
\hline IP-10 & -60.0868 & 92.6195 & 0.6615 \\
\hline MCP 1 & -28.1585 & 103.9692 & 0.2471 \\
\hline MCP & -11.6111 & 21.6422 & 0.5380 \\
\hline MIP-1alpha & 112.6877 & 41.7140 & 0.3314 \\
\hline MIP-1beta & -47.6089 & 85.4206 & 0.5599 \\
\hline PDGF-AB/BB70 & -98.9755 & 4306.0748 & 0.0604 \\
\hline RANTES & 107.6555 & 95.9740 & 0.9068 \\
\hline CD40 & 371.0274 & 953.0365 & 0.3716 \\
\hline sIL-2Ralpha & -3.6297 & 8.1739 & 0.4344 \\
\hline TGFalpha & -5.8105 & 2.9514 & 0.4942 \\
\hline TNFalpha & -1.4192 & 1.8143 & 0.7978 \\
\hline TNFbeta & -7.0867 & 2.5105 & 0.3104 \\
\hline VEGF & -13.0654 & 8.5096 & 0.6531 \\
\hline
\end{tabular}

* Lower limit of $95 \%$ Confidence Interval

** Upper limit of $95 \%$ Confidence Interval 
Table 2 Peripheral blood variables and comparisons in control and Mexico City children.

\begin{tabular}{|c|c|c|c|c|}
\hline \multicolumn{5}{|c|}{ Groups } \\
\hline & $\begin{array}{l}\text { Controls } \\
N=15\end{array}$ & $\begin{array}{c}\text { Mexico City } \\
\qquad=\mathbf{2 0}\end{array}$ & $\begin{array}{l}95 \% \text { Confidence Interval } \\
\text { lower/upper limits }\end{array}$ & $p$ value \\
\hline Haemoglobin / g dL ${ }^{-1}$ & $13.0 \pm 1.2$ & $13.8 \pm 0.6$ & $-0.0073 / 1.5273$ & 0.05 \\
\hline Haematocrit / \% & $38.5 \pm 3.5$ & $40.4 \pm 1.8$ & $-0.2246 / 3.9480$ & 0.07 \\
\hline White blood cells $/ \times 10^{3} \mathrm{~L}^{-1}$ & $7460 \pm 1464$ & $5635 \pm 1001$ & $-3081.8506 /-195.1894$ & 0.02 \\
\hline Neutrophils / \% & $52.1 \pm 7.3$ & $46.5 \pm 8.4$ & $-11.0289 /-0.1244$ & 0.04 \\
\hline Lymphocytes / \% & $38.7 \pm 7.5$ & $43.9 \pm 9$ & $-0.5440 / 10.9007$ & 0.07 \\
\hline Monocytes / \% & $5.6 \pm 1.8$ & $7.4 \pm 1.7$ & $0.5693 / 3.0774$ & 0.0059 \\
\hline Eosinophils / \% & $2.8 \pm 1.9$ & $1.6 \pm 1.0$ & $-2.4372 /-0.0895$ & 0.0362 \\
\hline Neutrophils total & $3.8 \pm 0.9$ & $2.6 \pm 0.67$ & $-1.8623 /-0.6544$ & 0.0003 \\
\hline Lymphocytes total & $2.8 \pm 0.7$ & $2.4 \pm 0.6$ & $-0.8728 / 0.0828$ & 0.010 \\
\hline Platelets & $309467 \pm 47715$ & $331800 \pm 57239$ & $-13827 / 58494$ & 0.21 \\
\hline Glucose / mg dL ${ }^{-1}$ & $79.6 \pm 11.3$ & $81.0 \pm 7.3$ & $-6.2767 / 9.0254$ & 0.71 \\
\hline Calcium / mg dL ${ }^{-1}$ & $9.9 \pm 0.25$ & $9.5 \pm 0.2$ & $-0.5729 /-0.2048$ & 0.0002 \\
\hline Phosphorus / mg dL ${ }^{-1}$ & $5.14 \pm 0.59$ & $5.3 \pm 0.39$ & $-0.1816 / 0.620$ & 0.26 \\
\hline Cholesterol / mg dL ${ }^{-1}$ & $158.9 \pm 17.7$ & $167.8 \pm 37.0$ & $-13.7331 / 31.0869$ & 0.42 \\
\hline Triglycerides / $\mathrm{mg} \mathrm{dL}^{-1}$ & $109.8 \pm 81.5$ & $97.3 \pm 42.6$ & $-65.4600 / 40.4344$ & 0.62 \\
\hline $\mathrm{AST} / \mathrm{UI} \mathrm{L}^{-1}$ & $32.2 \pm 3.2$ & $31.2 \pm 8.0$ & $-57517 / 3.6902$ & 0.65 \\
\hline ALT / UI L-1 & $15.1 \pm 3.2$ & $19.4 \pm 12.8$ & $-2.9757 / 11.6013$ & 0.22 \\
\hline GGT / UI L-1 & $27.8 \pm 2.1$ & $16.0 \pm 2.9$ & $-13.7646 /-9.7944$ & $<0.0001$ \\
\hline ALP / UI L ${ }^{-1}$ & $235.5 \pm 31.8$ & $239.4 \pm 47.4$ & $-27.2325 / 35.0889$ & 0.79 \\
\hline IL-6 & $2.27 \pm 1.5$ & $4.8 \pm 2.3$ & $1.0413 / 4.0187$ & 0.001 \\
\hline
\end{tabular}

Note: The numerical values shown in the table represent means \pm 1 standard deviation as well as $95 \%$ confidence intervals and $p$ values of two sample t-test for difference between two group means. (AST= aspartate aminotransferase, ALT=alanine aminotransferase, $G G T=$ gamma glutamyl transferase, $A L P=$ total alkaline phosphatase).

\section{TLR4 genotyping}

All included children lack the Asp299Gly Toll-like receptor-4 (TLR-4) polymorphism, which is associated with a blunted response to lipopolysacharide (23).

\section{Nutritional intake findings}

The nutritional intake based on a seven-day recall showed no differences in control and Mexico City children (Table 3), except for the intake of ascorbic acid that was significantly higher in Mexico City children $(p=0.005)$. Both cohorts exhibited a Vitamin $\mathrm{D}$ intake below the daily requirement of $600 \mathrm{UI}$, the deficiency being more severe in MC children [(429 \pm 70$)$ IU and $(389 \pm 141)$ IU CTL and MC respectively]. For both cohorts, the Ca intake was near the lower acceptable threshold of the requirement for age (800 to 1200) mg day ${ }^{-1}$.

\section{Bone age results}

There was a significant difference between chronological and bone age in Mexico City children $(p=0.03)$ based on the evaluation of the left wrist (20), a difference that was not seen in the controls $(p=0.15)$.

\section{DXA results}

There were no statistical differences between groups in the BMD Z scores in the different anatomical regions (Table 4). Given the importance of inflammation and air pollution, we performed a linear regression analysis between total peripheral neutrophils and DXA and other $\mathrm{CBC}$ variables including $\mathrm{WBC}$, percentages and total numbers of monocytes, lymphocytes, etc. The analysis showed a positive association between the percentage of body fat and neutrophils $\left(r^{2}=0.12\right.$, $p=0.03$ ), while the number of monocytes correlated with IL6 $\left(r^{2}=0.22, p=0.0116\right)$.

\section{DISCUSSION}

Mexico City six-year-olds exhibit significantly higher concentrations of IL-6, have a Vitamin D insufficiency $(24,25)$, and spend less time outdoors. 


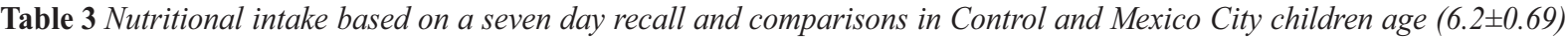
years

\begin{tabular}{|c|c|c|c|c|c|}
\hline & \multicolumn{2}{|c|}{ Groups } & \multirow[b]{2}{*}{$\begin{array}{l}\text { Confidence Intervals } \\
\text { lower/upper limits }\end{array}$} & \multirow[b]{2}{*}{$p$ value } & \multirow[b]{2}{*}{ RDA* } \\
\hline & $\begin{array}{c}\text { Controls } \\
N=15\end{array}$ & $\begin{array}{c}\text { Mexico City } \\
\qquad=\mathbf{2 0}\end{array}$ & & & \\
\hline Energy / kcal day ${ }^{-1}$ & $1438 \pm 233$ & $1463 \pm 234$ & $-137.8892 / 188.6137$ & 0.75 & 1600 to 1700 \\
\hline Protein / $\mathrm{g}_{\text {day }}{ }^{-1}$ & $58.5 \pm 9.2$ & $62.5 \pm 12.8$ & $-3.7024 / 11.5485$ & 0.30 & $1.35 \mathrm{~g} \mathrm{~kg}^{-1}$ b.m. \\
\hline Carbohydrates / g & $177 \pm 39.8$ & $174.6 \pm 32$ & $-29.0989 / 22.7039$ & 0.80 & $\begin{array}{c}(50 \text { to } 60) \% \text { of } \\
\text { energy }\end{array}$ \\
\hline Fat / g & $54.8 \pm 10.4$ & $58.1 \pm 11.9$ & $-4.4168 / 10.9994$ & 0.39 & $\begin{array}{c}(25 \text { to } 30) \% \text { of } \\
\text { energy }\end{array}$ \\
\hline Fibre (g) & $6.3 \pm 2.2$ & $6.1 \pm 2.1$ & $-1.6960 / 1.4359$ & 0.86 & $\begin{array}{c}(8 \text { to } 10) \text { g per } \\
1000 \mathrm{kcal}\end{array}$ \\
\hline Cholesterol / mg & $277 \pm 68$ & $325 \pm 100$ & $-9.6840 / 106.9574$ & 0.09 & $\begin{array}{c}100 \text { mg per } 1000 \\
\text { kcal }\end{array}$ \\
\hline Calcium / mg & $824.7 \pm 67.4$ & $785.4 \pm 193$ & $-135.2528 / 56.5389$ & 0.40 & 800 to 1200 \\
\hline Phosphorus / mg & $1006.5 \pm 222$ & $953.2 \pm 192$ & $-200.5850 / 93.8912$ & 0.46 & 800 \\
\hline Iron / mg & $10.6 \pm 4.0$ & $11 \pm 3.8$ & $-2.4078 / 3.1418$ & 0.78 & 15 \\
\hline Magnesium / mg & $136.8 \pm 19$ & $146 \pm 37$ & $-10.1170 / 29.9978$ & 0.31 & 120 \\
\hline Potassium / mg & $1464 \pm 259$ & $1647 \pm 429$ & $-55.4186 / 421.5431$ & 0.12 & 1400 to 1600 \\
\hline Retinol / $\mu \mathrm{g}$ & $647 \pm 230$ & $792 \pm 281$ & $-30.4543 / 321.6284$ & 0.10 & 500 to 700 \\
\hline Ascorbic acid / mg & $48.9 \pm 26$ & $89.8 \pm 52$ & $13.2615 / 68.4444$ & 0.005 & 45 \\
\hline Vitamin D / IU & $429 \pm 70$ & $389 \pm 141$ & $-114.6085 / 34.6478$ & 0.28 & 600 \\
\hline
\end{tabular}

Note: The numerical values shown in the table represent means \pm 1 standard deviation as well as $95 \%$ confidence intervals and $p$ values of two sample t-test for difference between two group means. *Recommended dietary allowance (RDA) for age and gender.

Even though changes in the DXA Z scores are not evident in this small cohort, the high concentrations of IL-6 and the vitamin D insufficiency are cause for serious concern. Interleukin 6 plays a key role in bone resorption and osteoporosis (26-32). Bones are targets of inflammation, with inflammatory cytokines promoting bone resorption which results in systemic bone loss (30). A clear example of an inflammatory entity and a bone detrimental effect is inflammatory bowel disease (IBD) (33). Patients with IBD demonstrate elevated levels of IL-6, TNF $\alpha$ and IL1 $\beta$, all of which are associated with osteoclastic activity through the activation of $\mathrm{p} 38$ mitogen-activated protein kinase (MAPK) pathways $(33,34)$. Our previous study on older Mexico City children had shown elevated concentrations of TNF $\alpha$ and $\operatorname{IL} 1 \beta(5)$, thus a osteoclastic synergistic action is likely to be taking place as the children grow up in their polluted environment. TNF $\alpha$ and RANKL interact to potentiate two osteoclastogenic pathways: NFKB and the stress activated protein kinase/c-Jun NH2-terminal kinase activity (36).

TLR4 plays a critical role in the activation of IL-6 producing leukocytes (32) and LPS promotes osteoclast activity and bone resorption (37). Both associations are also very relevant in Mexico City where children are exposed to significant concentrations of lipopolysaccharides associated with particulate matter (6). Since $85 \%$ of the Mexican population lacks the Asp299Gly Toll-like receptor-4 (TLR-4) polymorphism associated with a blunted response to lipopolysacharide (Calderón-Garcidueñas personal data), most Mexican children will be responsive to LPS and the activation of TLR4.

The characterization of inflammatory osteoclastic pathways in exposed children, along with the genotyping of TLR4 key polymorphisms, is mandatory to define whether critical mediators of bone loss are up-regulated and how bone responses evolve as the child grows up.

Exposure to sunlight is key for the skin conversion of 7-dehydrocholesterol to pre-vitamin $\mathrm{D}_{3}$ and vitamin $\mathrm{D}_{3}$ however, in the setting of air pollution, these children get less UV light, spend less time outdoors, and their skin phototype is mostly type IV. All of these factors act synergistically to decrease Vitamin D availability. These issues are important for our paediatric populations because air pollution reduces 
Table 4 Bone mineral density $\left(B M D / \mathrm{g} \mathrm{cm}^{-2}\right) Z$ score, $95 \%$ confidence intervals, mean and SD, and $\mathrm{p}$ values between Controls and Mexico City children

\begin{tabular}{|c|c|c|c|c|c|}
\hline BMD Region & $p$ values & LCI95* & UCI95** & Mean & SD \\
\hline BMD Total & 0.2271 & -0.0119 & 0.0478 & 0.3918 & 0.8215 \\
\hline BMD head & 0.0537 & -0.0013 & 0.1484 & 0.6359 & 0.8056 \\
\hline BMD pelvis & 0.6361 & -0.0394 & 0.0244 & -0.1914 & 1.3711 \\
\hline BMD column & 0.0885 & -0.0031 & 0.0426 & 0.6648 & 1.2386 \\
\hline BMD L1L4 & 0.4760 & -0.0306 & 0.0640 & 0.2692 & 1.1635 \\
\hline BMD L1 & 0.1316 & -0.0133 & 0.0970 & 0.5795 & 1.1701 \\
\hline BMD L2 & 0.5721 & -0.0319 & 0.0567 & 0.2101 & 1.1726 \\
\hline BMD L3 & 0.2596 & -0.0217 & 0.0779 & 0.4236 & 1.1803 \\
\hline BMD L4 & 0.3205 & -0.0223 & 0.0660 & 0.4228 & 1.4769 \\
\hline BMD left femoral neck & 0.9056 & -0.0559 & 0.0628 & 0.0367 & 0.7372 \\
\hline BMD right femoral neck & 0.8636 & -0.0736 & 0.0621 & -0.0553 & 0.8348 \\
\hline BMD mean femoral neck & 0.9686 & -0.0641 & 0.0617 & -0.0124 & 0.7907 \\
\hline BMD left sup femoral neck & 0.6477 & -0.0492 & 0.0777 & 0.1452 & 0.8001 \\
\hline BMD right sup femoral neck & 0.6768 & -0.0903 & 0.0595 & -0.1371 & 0.8858 \\
\hline BMD mean femoral neck & 0.9857 & -0.0687 & 0.0675 & -0.0058 & 0.8463 \\
\hline BMD Ward left & 0.6905 & -0.0893 & 0.0600 & -0.1256 & 0.7822 \\
\hline BMD Ward right & 0.3624 & -0.1316 & 0.0498 & -0.2877 & 0.7687 \\
\hline BMD Ward mean & 0.4932 & -0.1097 & 0.0543 & -0.2157 & 0.7690 \\
\hline BMD right diaphysis & 0.8602 & -0.0799 & 0.0946 & 0.0683 & 0.6181 \\
\hline BMD right femur total & 0.9347 & -0.0766 & 0.0829 & 0.0312 & 0.5885 \\
\hline BMD left diaphysis & 0.8536 & -0.0764 & 0.0913 & 0.0676 & 0.6119 \\
\hline BMD left femur total & 0.5751 & -0.0492 & 0.0860 & 0.2005 & 0.5695 \\
\hline BMD T5 & 0.2428 & -0.0870 & 0.2860 & 0.7940 & 1.1416 \\
\hline BMD T6 & 0.6886 & -0.2116 & 0.2937 & 0.2396 & 0.8105 \\
\hline BMD T7 & 0.2781 & -0.1839 & 0.0581 & -0.9788 & 2.2122 \\
\hline
\end{tabular}

* Lower limit of $95 \%$ confidence interval

** Upperlimit of $95 \%$ confidence interval

UV light by $20 \%$ on average (22) and the children's diet becomes a critical source of vitamin $\mathrm{D}$ due to the inadequate exposure to sunshine (38). Our cohorts have an adequate caloric, protein, fat and carbohydrate intake but restricted access to fortified Vitamin D foods and a low calcium intake. In a recent study on Mexican children, Elizondo-Montemayor et al. (39) found that $62.1 \%$ of urban children had an insufficiency of 25 OHD (21 to 29$) \mathrm{ng} \mathrm{mL}^{-1}$ and $20.2 \%$ had a deficiency $\left(<20 \mathrm{ng} \mathrm{mL}^{-1}\right)$. The problem of Vitamin D deficiency among Mexican children is a serious health issue shared with one billion people worldwide $(25,39)$.

Given that the majority of bone mass is attained during adolescence and young adulthood, with almost $90 \%$ of skeletal mass accumulated by age 18 (40), factors that influence bone mass accrual during growth, including mechanical factors and calcium and vitamin D intake, become critical in populations like such as that of Mexico. Thus, we face serious social issues involving the negative impact on our children's bone health: 1. during the lifetime of our cohorts, there had been a significant rise in crime and violence in neighbourhoods (41) resulting in a marked decrease in the use of public spaces that used to host much of the children's outdoor activities after school; 2 . There are 52 million people in the country with incomes below the poverty line, including 11.7 million in extreme poverty, $41 \%$ of who are children (42). Twenty one million children are in households below the poverty level and $77 \%$ of these children live in urban areas. Poverty, food insecurity, and the deteriorating security conditions are affecting the 
children's quality of life and potentially even their bone health.

Bone health is critical in childhood and adolescent years (43). A compromised bone with decreased strength and altered microarchitecture will have detrimental effects during childhood and may leave permanent bone damage $(43,44)$. Low bone density in children is a serious issue; one that remains difficult to evaluate particularly in terms of long-term consequences (44-48). The association of low BMD and a history of at least one fragility fracture are required in order to diagnose osteoporosis in children $(44,47)$. The evidence of an association between lower than average BMD and a higher fracture rate, along with sustaining repeated fractures, especially at sites specific for bone weakness (i.e., the ultradistal radius), are pieces of information we need to include in future studies on older paediatric populations exposed to pollution.

Our studies in Mexico City have shown that lifelong exposures to a polluted environment, including above standard concentrations of $\mathrm{PM}_{2.5}$, are associated with significant systemic inflammation and immunodysregulation (4-6). The marked reduction of peripheral blood neutrophils observed in highly exposed Mexico City children in this work and in previous studies, along with high concentrations of endothelin-1, have been taken as strong evidence for endothelial activation and inflammation $(4,6)$ Moreover, the increase in monocytes has been described upon exposure to particulate matter (49). An interesting association in this work is the positive relationship between body fat and the numbers of peripheral neutrophils, as well as between monocytes and IL-6 concentrations in keeping with the literature pointing to low-grade systemic inflammation related to higher levels of body fat in children $(50,51)$.

The impact of the increased production of inflammatory mediators with osteoclastic activity has to be taken into account when selecting DXA reference urban populations from polluted cities (52). Especially relevant are cities with concentrations of particulate matter (PM) above the current US National Ambient Air Quality Standards, and since people travel to and from larger cities, PM exposures should be taken into consideration through their well-documented systemic effects (9).

This pilot study is limited to the small number of children included; however, since the cohorts represent clinically healthy matched children with unremarkable clinical histories and representative of low and high polluted urban areas, the results will be useful for planning future longitudinal studies.

In summary, this pilot study on Mexico City sixyear-olds is a warning to paediatricians to carefully assess bone health in children residents of polluted megacities and small communities with high PM pollution, taking into consideration the presence of systemic inflammation and Vitamin D and calcium dietary deficiencies $(53,54)$. There is a lack of appreciation among paediatricians that vitamin D status and physical activity are critical for skeletal health in young children and that the physician's role is to provide recommendations to maximize the health of each individual child $(25,55)$. More paediatric research is needed to characterize the changes in bone metabolism in the setting of urban air pollution; measurements of circulating levels of 25hydroxyvitamin D [25(OH)D], serum calcidiol $(25$ $\mathrm{OH}$ vitamin $\mathrm{D}(3)$, and the parathyroid hormone ought to be included.

There is urgent need to assess protective measures and nutritional supplementation in disadvantaged highly exposed Mexico City children.

The impact of air pollution, nutritional deficiencies, urban insecurity and poverty may have long-term bone detrimental outcomes in exposed urban paediatric populations, potentially increasing their risk of low bone mass and osteoporosis.

\section{Acknowledgements}

This work is supported in part by P20 RR015583.

\section{REFERENCES}

1. Stein J, Schettler T, Wallinga D, Valenti M. In harm's way: toxic threats to child development. J Dev Behav Pediatr 2002;23(Suppl 1):S13-22.

2. Wigle DT, Arbuckle TE, Walker M, Liu S, Krewskin D. Environmental hazards: evidence for effects on child health. J Toxicol Environ Health B Crit Rev 2007;10:3-39.

3. Calderón-Garcidueñas L, Mora-Tiscareño A, Fordham LA, Valencia-Salazar G, Chung CJ, Rodriguez-Alcaraz A, Paredes R, Variakojis D, Villarreal-Calderón A, Flores-Camacho L, Antunez-Solis A, Henríquez-Roldán C, Hazucha MJ. Respiratory damage in children exposed to urban pollution. Pediatr Pulmonol 2003;36:148-61.

4. Calderón-Garcidueñas L, Vincent R, Mora-Tiscareño A, Franco-Lira M, Henríquez-Roldán C, Barragán-Mejía G, Garrido-García L, Camacho-Reyes L, Valencia-Salazar G, Paredes R, Romero L, Osnaya H, Villarreal-Calderón R, Torres-Jardón R, Hazucha MJ, Reed W. Elevated plasma endothelin-1 and pulmonary arterial pressure in children exposed to air pollution. Environ Health Perspect 2007;115:1248-53. 
5. Calderón-Garcidueñas L, Villarreal-Calderon R, ValenciaSalazar G, Henríquez-Roldán C, Gutiérrez-Castrellón P, Torres-Jardón R, Osnaya-Brizuela N, Romero L, TorresJardón R, Solt A, Reed W. Systemic inflammation, endothelial dysfunction, and activation in clinically healthy children exposed to air pollutants. Inhal Toxicol 2008;20:499-506.

6. Calderón-Garcidueñas L, Macias-Parra M, Hoffman HJ, Valencia-Salazar G, Henríquez-Roldán C, Osnaya N, Monte OC, Barragán-Mejía G, Villarreal-Calderon R, Romero L, Granada-Macías M, Torres-Jardón R, Medina-Cortina H, Maronpot RR. Immunotoxicity and environment: immunodysregulation and systemic inflammation in children. Toxicol Pathol 2009;37:161-9.

7. Calderón-Garcidueñas L, Kavanaugh M, Block M, D'Angiulli A, Delgado-Chávez R, Torres-Jardón R, González-Maciel A, Reynoso-Robles R, Osnaya N, Villarreal-Calderon R, Guo R, Hua Z, Zhu H, Perry G, Diaz P. Neuroinflammation, Alzheimer's disease-associated pathology and down regulation of the Prion-related protein in air pollution exposed children and young adults. J Alzheimer Dis 2012;28:93107.

8. Calderón-Garcidueñas L, Engle R, Mora-Tiscareño A, Styner M, Gómez-Garza G, Zhu H, Jewells V, Torres-Jardón R, Romero L, Monroy-Acosta ME, Bryant C, GonzálezGonzález LO, Medina-Cortina H, D’Angiulli A. Exposure to severe urban air pollution influences cognitive outcomes, brain volume and systemic inflammation in clinically healthy children. Brain Cogn 2011;77:345-55.

9. Brook RD, Rajagopalan S, Pope CA $3^{\text {rd }}$, Brook JR, Bhatnagar A, Diez-Roux AV, Holguin F, Hong Y, Luepker RV, Mittleman MA, Peters A, Siscovick D, Smith SC Jr, Whitsel L, Kaufman JD, American Heart Association Council on Epidemiology and Prevention, Council on the Kidney in Cardiovascular Disease, and Council on Nutrition, Physical Activity and Metabolism. Particulate matter air pollution and cardiovascular disease: An update to the scientific statement from the American heart Association. Circulation 2010;121:233178.

10. Nolan A, Naveed B, Comfort AL, Ferrier N, Hall CB, Kwon S, Kasturiarachchi KJ, Cohen HW, Zeig-Owens R, Glaser MS, Webber MP, Aldrich TK, Rom WN, Kelly K, Prezant DJ, Weiden MD. Inflammatory biomarkers predict airflow obstruction after exposure to World Trade Center dust. Chest 2012;142:412-8.

11. Caloca-Moreno V, Galindo-Estrada I, Frenk S. Aspectos biometereológicos en el raquitismo carencial, in Spanish. Arch Invest Med (Mex) 1973;4:115-24.

12. Balasubramanian S, Ganesh R. Vitamin D deficiency in exclusively breast-fed infants. Indian J Med Res 2008;127:2505 .

13. Nishimoto N, Kishimoto T. Interleukin-6: from bench to bedside. Nat Clin Pract Rheumatol 2006;2:619-26.

14. Alvaer K, Meyer HE, Falch JA, Nafstad P, Søgaard AJ. Outdoor air pollution and bone mineral density in elderly men-the Oslo Health Study. Osteoporos Int 2007;18:166974.

15. Molina LT, Kolb CE, de Foy B, Lamb BK, Brune WH, Jimenez JL, Ramos-Villegas R, Sarmiento J, ParamoFigueroa VH, Cárdenas B, Gutierrez-Avedoy V, Molina MJ. Air quality in North America's most populous city - overview of the MCMA-2003 campaign. Atmos Chem Phys 2007;7:2447-73.
16. Villarreal-Calderón A, Acuña H, Villarreal-Calderón J, Garduño M, Henríquez-Roldán CF, Calderón-Garcidueñas L, Valencia-Salazar G. Assessment of physical education time and alter-school outdoor time in elementary and middle school students in South Mexico City: the dilemma between physical fitness and the adverse health effects of outdoor pollutant exposure. Arch Environ Health 2002;57:450-60.

17. Li G, Bei N, Tie X, Molina LT. Aerosol effects on the photochemistry in Mexico City during MCMA-2006/ MILAGRO campaign. Atmos Chem Phys 2011;11:516982.

18. Marley NA, Gaffney JS, Castro T, Salcido A, Frederick JE. Measurements of aerosol absorption and scattering in the Mexico City Metropolitan Area during the MILAGRO field campaign: a comparison of results from the $\mathrm{T} 0$ and $\mathrm{T} 1$ sites. Atmos Chem Phys 2009;9:189-206.

19. Fitzpatrick TB. The validity and practicality of sun-reactive skin type I through VI. Arch Dermatol 1988;124:869-71.

20. Greulich WW, Pyle SI. Radiographic Atlas of Skeletal Development of the Hand and Wrist. $2^{\text {nd }}$ ed. Stanford (CA): Stanford University Press; 1959.

21. Gobierno del Estado de México. Plan Municipal de Desarrollo Urbano de Polotitlán. H. Ayuntamiento de Polotitlán. Secretaría de Desarrollo Urbano. Gobierno del Estado de México, in Spanish 2008.

22. Acosta LR, Evans WFJ. Design of the Mexico City UV monitoring network: UV-B measurements at ground level in the urban environment. J Geophys Res 2000;116:5017-26.

23. Garantziotis S, Hollingsworth JW, Zaas AK, Schwartz DA. The effect of Toll-like receptors and Toll-like receptors genetics in human disease. Annu Rev Med 2007;59:34359.

24. Institute of Medicine. Dietary References Intakes: Calcium, Phosphorus, Magnesium, Vitamin D, and Fluoride. Washington (DC): National Academy Press; 1997.

25. Pekkinen M, Viljakainnen H, Saarnio E, Lamberg-Allardt C, Mäkitie $\mathrm{O}$. Vitamin $\mathrm{D}$ is a major determinant of bone mineral density at school age. PLoS One 2012;7:e40090.

26. Stea S, Visentin M, Granchi D, Clapetti G, Donati ME, Sudanese A, Zanotti C, Toni A. Cytokines and osteolysis around total hip prostheses. Cytokine 2000;12:1575-9.

27. Haynes DR. Inflammatory cells and bone loss in rheumatoid arthritis. Arthritis Res 2007;9:104-6.

28. Preston RD, Meinberg TA, Payne JB, Schmid MJ, Lee HM, Golub LM, Marx DB, Reinhardt RA. Inflammatory mediator release following bone grafting in humans: a pilot study. J Clin Periodontol 2007;34:797-804.

29. TuszynskaA, KrzeskiA, Postuba M, Paczek L, WyczalkowskaTomasik A, Gornicka B, Pykalo R. Inflammatory cytokines gene expression in bone tissue from patients with chronic rhinosinusitis - a preliminary study. Rhinology 2010;48:4159.

30. Geusens P, Lerns WF. Osteoimmunology and osteoporosis. Arthritis Res Ther 2011;13:242-50.

31. Rufo A, Del Fattore A, Capulli M, Carvello F, De Pasquale L, Ferrari S, Pierroz D, Morandi L, De Simone M, Rucci N, Bertini E, Bianchi ML, De Benedetti F, Teti A. Mechanisms inducing low bone density in Duchenne muscular dystrophy in mice and humans. J Bone Miner Res 2011;26:1891-903.

32. Chen J, Hartono JR, John R, Bennett M, Zhou XJ, Wang Y, Wu Q, Winterberg PD, Nagami GT, Lu CL. Early interleukin 
6 production by leukocytes during ischemic acute kidney injury is regulated by TLR4. Kidney Int 2011;80:504-15.

33. Agrawal M, Arora S, Li J, Rahmani R, Sun L, Steinlauf AF, Mechanick JI, Zaidi M. Bone, inflammation and inflammatory bowel disease. Curr Osteoporos Rep 2011;9:252-7.

34. Kumar S, Votta BJ, Rieman DJ, Badger AM, Gowen M, Lee JC. IL1 and TNF-induced bone resorption is mediated by p38 mitogen activated protein kinase. J Cell Physiol 2001;187:294-303.

35. Paganelli M, Albanese C, Borrelli O, Civitelli F, Canitano N, Viola F, Passariello R, Cucchiara S. Inflammation is the main determinant of low bone mineral density in pediatric inflammatory bowel disease. Inflamm Bowel Dis 2007;13:41623.

36. Lam J, Takesshita S, Baker JE, Kanagawa O, Ross JP, Tewitelbaum SL. TNF $\alpha$ induces osteoclastogenesis by direct stimulation of macrophages exposed to permissive levels of RANK ligand. J Clin Invest 2000;106:1481-8.

37. Xing Q, de Vos P, Faas MM, Ye Q, Ren Y. LPS promotes pre-osteoclast activity by up-regulating CXCR4 via TLR-4. J Dental Res 2011;90:157-62.

38. Wharton B, Bishop N. Rickets. Lancet 2003;362:1389400.

39. Elizondo-Montemayor L, Ugalde-Casas PA, SerranoGonzalez M, Cuello-Garcia CA, Borbolla-Escoboza JR. Serum 25-hydroxyvitamin D concentration, life factors and obesity in Mexican children. Obesity 2010;18:1805-11.

40. Bailey DA, McKay HA, Mirwald RL, Crocker PR, Faulkner RA. A six-year longitudinal study of the relationship of physical activity to bone mineral accrual in growing children: the University of Saskatchewan bone mineral accrual study. J Bone Min Res 1999;14:1672-9.

41. Davis DE. The Giuliani Factor: Crime, Zero Tolerance Policing and the Transformation of the Public Sphere in downtown Mexico City, 2010 [displayed 13 December 2012]. Available at http://www.hks.harvard.edu/inequality/ Seminar/Papers/Davis09.doc
42. Consejo Nacional de Evaluación de la Política de Desarrollo Social [displayed 13 December 2012]. Available at http:// www.coneval.gob.mx/cmsconeval/rw/pages/medicion/index. es.do

43. Caradonna P, Rigante D. Bone health as a primary target in the pediatric age. Eur Rev Med Pharmacol Sci 2009;13:11728.

44. Bianchi ML. Osteoporosis in children and adolescents. Bone 2007;41:486-95.

45. Borges JLC, Brandão CMA. Low bone mass in children and adolescents. Arq Bras Endocrinol Metab 2006;50:775-82.

46. Manias K, McCabe D, Bishop N. Fractures and recurrent fractures in children; varying effects of environmental factors as well as bone size and mass. Bone 2006;39:652-7.

47. Ward LM, Glorieux FH. The spectrum of pediatric osteoporosis. In: Glorieux FH, Pettifor JM, Jüppner H, editors. Pediatric bone: biology and diseases. San Diego (CA): Academic Press; 2003.

48. Boyce AM, Gafni RI. Approach to the child with fractures. J Clin Endocrinol Metab 2011;96:1943-52.

49. Goto Y, Ishii H, Hogg JC, Shih CH, Yatera K, Vincent R, van Eeden SF. Particulate matter air pollution stimulates monocyte release from the bone marrow. Am J Respir Crit Care Med 2004;170:891-7.

50. Roth CL, Kratz M, Ralston MM, Reinehr T. Changes in adipose-derived inflammatory cytokines and chemokines after successful lifestyle intervention in obese children. Metabolism 2011;60:445-52.

51. Dalmas E, Tordiman J, Guerre-Millo M, Clement K. Le tissu adipeux Un nouveau terrain de jeu pour les cellules immunitaires [Adipose tissue, a new playground for immune cells, in French]. Med Sci (Paris) 2011;11:993-9.

52. Tamayo J, Díaz R, Lazcano-Ponce E, Muñoz M, Huitrón G, Halley E, Diaz-Montiel JC, Mudgal J, Hernández-Avila M, Salmerón J. Reference values for areal bone mineral density among healthy Mexican population. Salud Pública Méx 2009;51(Suppl 1):S56-82. 


\section{Sažetak}

\section{IZLOŽENOST GRADSKOM ONEČIŠĆENJU ZRAKA I ZDRAVLJE KOSTIJU U KLINIČKI ZDRAVOJ ŠESTOGODIŠNJOJ DJECI}

Onečišćenje zraka uzrokuje sistemsku upalu, kao i respiratorne, miokardijalne i moždane upale kod djece. Čimbenici iz okoliša utječu na vršnu koštanu masu. Ispitali smo hipotezu da šestogodišnjaci s cjeloživotnom izloženosti gradskom onečišćenju zraka imaju drugačije upalne pokazatelje i mineralnu gustoću kostiju (BMD) od djece iz gradova s niskom razinom onečišćenja kada usporedimo tjelesni indeks mase, povijest dojenja, fototip kože, dob, spol i društveno-ekonomski položaj. Ova pilot-studija uključuje dvadesetero djece iz glavnoga grada Méxica $(6,17 \pm 0,63)$ godina i petnaestero kontrolne djece $(6,27 \pm 0,76)$ godina. Obavili smo cjelovite pedijatrijske preglede, prikupili povijesti vanjske izloženosti, sedmodnevne analize prehrane, serumske razine upalnih pokazatelja i dvoenergetsku apsorpciometriju X-zraka (DXA). Djeca iz Méxica imala su značajno više koncentracije IL-6 ( $p=0,001)$, izrazito smanjen ukupni broj krvnih neutrofila $(p=0,0002)$ i povećan broj monocita $(p=0,005)$. Djeca iz Méxica također su unosila nedovoljnu količinu vitamina D i provodila manje vremena na otvorenome od kontrolnih ispitanika $(p<0,001)$, i to u okružju obilježenom smanjenom UV svjetlošću te koncentracijama ozona i čestične materije iznad standardnih vrijednosti. Nije bilo značajnih razlika između kohorta u Z-vrijednostima DXA. Učinci sistemske upale, insuficijencije vitamina $\mathrm{D}$, onečišćenja zraka, gradskog nasilja i siromaštva mogu imati dugoročne štetne posljedice na kosti u izloženim pedijatrijskim populacijama kako one odrastaju, povećavajući tako njihov rizik od smanjenja koštane mase i osteoporoze. Pri odabiru referentne populacije za DXA bi se ubuduće trebala uzimati u obzir i izloženost onečišćenom zraku.

KLJUČNE RIJEČI: čestična materija, DXA, insuficijencija vitamina D, sistemska upala, UV svjetlo

\section{CORRESPONDING AUTHOR:}

Lilian Calderón-Garcidueñas, MD PhD

The Center for Structural and Functional Neurosciences,

The University of Montana

32 Campus Drive, 287 Skaggs Building, Missoula, MT 59812

E-mail: lilian.calderon-garciduenas@umontana.edu 